\title{
Inhibition of Mesangial Cell Proliferation by E2F Decoy Oligodeoxynucleotide In Vitro and In Vivo
}

\author{
Yohei Maeshima, ${ }^{\star}$ Naoki Kashihara, ${ }^{*}$ Tatsuji Yasuda, ${ }^{\ddagger}$ Hitoshi Sugiyama, ${ }^{\star}$ Takashi Sekikawa, ${ }^{*}$ Kazunori Okamoto, \\ Koichiro Kanao, ${ }^{*}$ Yuzo Watanabe, ${ }^{\S}$ Yashpal S. Kanwar, ${ }^{\star}$ and Hirofumi Makino* \\ *Department of Medicine III, ${ }^{\star}$ Department of Cellular Technology, Okayama University Medical School, Okayama 700, Japan; ${ }^{\S}$ Third

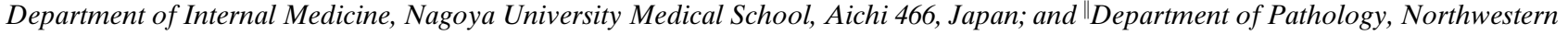 \\ University Medical School, Chicago, Illinois 60611
}

\begin{abstract}
The transcription factor E2F coordinately activates several cell cycle-regulatory genes. We attempted to inhibit the proliferation of mesangial cells in vitro and in vivo by inhibiting E2F activity using a 25-bp decoy oligodeoxynucleotide that contained consensus E2F binding site sequence (E2F-decoy) as a competitive inhibitor. The decoy's effect on human mesangial cell proliferation was evaluated by $\left[{ }^{3} \mathrm{H}\right]$ thymidine incorporation. The E2F decoy inhibited proliferation in a concentration-dependent manner, whereas a mismatch control oligodeoxynucleotide had little effect. Electrophoretic mobility shift assays demonstrated that the decoy's inhibitory effect was due to the binding of the decoy oligodeoxynucleotide to E2F. The effect of the E2F decoy was then tested in a rat anti-Thy 1.1 glomerulonephritis model. The E2F decoy oligodeoxynucleotide was introduced into the left kidney $36 \mathrm{~h}$ after the induction of glomerulonephritis. The administration of E2F decoy suppressed the proliferation of mesangial cells by $71 \%$. Furthermore, treatment with the E2F decoy inhibited the glomerular expression of proliferating cell nuclear antigen at the protein level as well as the mRNA level.

These findings indicate that decoy oligonucleotides can suppress the activity of the transcription factor E2F, and may thus have a potential in treating glomerulonephritis. $(J$. Clin. Invest. 1998. 101:2589-2597.) Key words: kidney • transcription factor - glomerulonephritis - cationic liposomes • transfection
\end{abstract}

\section{Introduction}

The proliferation of glomerular mesangial cells (MCs) ${ }^{1}$ as well as the expansion of the glomerular matrix is a central feature

Address correspondence to Naoki Kashihara, M.D., Department of Medicine III, Okayama University Medical School, 2-5-1 Shikatacho, Okayama 700, Japan. Phone: 81-86-223-7151 Ext. 7235; FAX: 8186-222-5214.

Received for publication 18 April 1997 and accepted in revised form 25 March 1998.

1. Abbreviations used in this paper: EMSA, electrophoretic mobilityshift assay; GAPDH, glyceraldehyde-3-phosphate dehydrogenase; GN, glomerulonephritis; MC, mesangial cell; MLV, multilamellar vesicle; ODN, oligodeoxynucleotides; PCNA, proliferating cell nuclear antigen; RT, reverse transcriptase.

J. Clin. Invest.

(C) The American Society for Clinical Investigation, Inc. 0021-9738/98/06/2589/09 \$2.00

Volume 101, Number 11, June 1998, 2589-2597

http://www.jci.org of various human glomerular diseases (1-3). MC proliferation characterizes many types of glomerulonephritis (GN), and is central to the development of glomerulosclerosis and renal failure $(1,3)$. Several growth factors and cytokines are involved in this process. Accordingly, several studies have attempted to suppress the proliferation of MCs by inhibiting specific mitogens (4). However, suppressing the activity of just one mitogen is not sufficient to inhibit MC proliferation.

$\mathrm{E} 2 \mathrm{~F}$ is a transcription factor that activates numerous genes that encode cell cycle regulatory proteins, including dihydrofolate reductase, c-myc, DNA polymerase $\alpha$, cdc2, and proliferating cell nuclear antigen (PCNA; reference 5-10). In this study, we attempted to inhibit E2F in vitro and in vivo, and thereby to prevent the coordinated transactivation of cell cycle regulatory genes involved in the progression of proliferative GN. For this purpose, we designed a double-stranded decoy oligodeoxynucleotide (ODN) that acts as a competitive inhibitor of E2F binding. We examined the antiproliferative effect of decoy-ODN against E2F on MC in vitro and in vivo.

\section{Methods}

Synthesis of decoy oligodeoxynucleotides. Double-stranded 25-bp ODNs were synthesized using an automated DNA synthesizer (Model 380B; Applied Biosystems, Inc., Foster City, CA). The ODNs were purified by column chromatography, lyophilized, and dissolved in culture medium. Concentrations of each ODN were determined spectrophotometrically. The E2F decoy ODN contains the consensus sequence of the E2F binding site identified in the promoter regions of several cellular genes (5-10). A mismatch control ODN also was synthesized (the 2-bp mismatch is underlined). The sequences of the oligomers used are as follows:

$\begin{array}{lr}\text { 25-mer E2F decoy ODN 5'-ATTTAAGTTTCGCGCCCTTTCTCAA-3' } \\ & \text { 3'-TAAATTCAAAGCGCGGGAAAGAGTT-5' } \\ \text { 25-mer mismatch } & \text { 5'-ATTTAAGTTTCGATCCCTTTCTCAA-3' } \\ \text { Control ODN } & \text { 3'-TAAATTCAAAGCTAGGGAAAGAGT-5' }\end{array}$

Mesangial cell preparation and culture. Human MCs were obtained and identified as described previously $(11,12)$. In brief, portions of human renal cortex that appeared normal on macroscopic inspection were obtained immediately after surgical nephrectomy for renal cell carcinoma. Glomeruli were isolated by differential sieving. The final preparation consisted of glomeruli without tubular fragments. Isolated glomeruli were cultured in RPMI 1640 medium (GIBCO BRL, Gaithersburg, MD) supplemented with $100 \mathrm{IU} / \mathrm{ml}$ penicillin (Meiji, Tokyo, Japan), $100 \mu \mathrm{g} / \mathrm{ml}$ streptomycin sulfate (Meiji) and $20 \%$ FCS (Armour, Kankakee, IL) at $37^{\circ} \mathrm{C}$ in a humidified $5 \% \mathrm{CO}_{2}$ atmosphere. Outgrowing cells were transferred for subculture. Cells were used between the fourth and seventh passage. The identity of the cells was confirmed by standard criteria $(13,14)$.

Analysis of the effects of decoy ODN on MC proliferation. MCs were seeded (day 0) at 5,000 cells per well in 96-well plates (Costar Corp., Cambridge, MA) and cultured in RPMI 1640 medium supple- 
mented with $20 \%$ FCS (growth medium) for $36 \mathrm{~h}$. The medium then was replaced with RPMI 1640 containing $0.2 \%$ FCS and incubated for another $60 \mathrm{~h}$ to synchronize the MCs into quiescence. On day 4, the medium was replaced with growth medium containing $20 \%$ FCS and E2F decoy or mismatch control ODN in triplicate wells. Commercially available cationic liposomes (Lipofectin Reagent; GIBCO BRL), were used to facilitate the transfection of ODNs into the MCs as described previously (15). Briefly, ODN dissolved in RPMI 1640 were mixed with Lipofectin, which were also dissolved in RPMI 1640 at a ratio of $1 \mathrm{nmol}: 1 \mu \mathrm{g}$, and incubated for $20 \mathrm{~min}$ at room temperature. The ODN-liposome complexes were added dropwise to each well (triplicate). The MCs were pulse labeled with [ $\left.{ }^{3} \mathrm{H}\right]$ thymidine $18 \mathrm{~h}$ after ODN addition, and $\left[{ }^{3} \mathrm{H}\right]$ thymidine incorporation was measured. In another series of experiments, the MCs were trypsinized $24 \mathrm{~h}$ after adding ODN (day 7) and stained with trypan blue to count viable cells.

To examine the transfection efficiency, ODNs (E2F-decoy) FITC-labeled at their $3^{\prime}$ and $5^{\prime}$ ends were transfected under the same conditions. Human MCs were cultured on 16-well chamber slides (Nunc, Inc., Naperville, IL) and FITC-labeled ODN $(2 \mu \mathrm{M})$ were introduced as described above for the unlabeled ODNs. The cells then were evaluated by an Olympus fluorescence microscope (Olympus, Tokyo, Japan).

In vivo transfer of ODNs. 5-wk-old male Wistar rats that weighed $\sim 150 \mathrm{~g}$ at the start of the experiments were obtained from Charles River Japan, Inc. (Atsugi, Kanagawa, Japan). The animals had free access to standard rat chow and water throughout the experimental period. Rat mesangial proliferative GN (anti-Thy $1.1 \mathrm{GN}$ ) was induced by the intravenous injection of the affinity-purified monoclonal antibody OX-7 (reference 16; $0.2 \mathrm{mg} / 100 \mathrm{~g}$ body weight). The antibody was a generous gift from Dr. Y. Watanabe (University of Nagoya, Nagoya, Japan). $36 \mathrm{~h}$ after the injection of the anti-Thy 1.1 antibody, the rats were anesthetized and the left renal artery and vein were transiently ligated. Multilamellar vesicle (MLV)-liposomes containing dioleoylphosphatidylethanolamine, dilauroylphosphatidylcholine, and $N$-(a-trimethylammonioacetyl)-didodecyl-D-glutamate chloride at a molar ratio of 1:2:2, were prepared as described previously (17). E2F decoy or mismatch control ODN (200 $\mu \mathrm{g}$ per animal) was preincubated with the MLV-liposomes for at least 20 min before it was injected via the left renal artery after flushing with $1 \mathrm{ml}$ normal saline. The ratio of MLV-liposomes to ODN, which had been determined in a preliminary study using cultured MC (data not shown), was $1 \mu \mathrm{mol}: 40 \mu \mathrm{g}$. Another group of anti-Thy $1.1 \mathrm{GN}-$ induced rats was injected with MLV-liposomes alone (vehicle). 5 min after the intra-arterial injection, the blood flow was restored by removing the temporal ligatures. On the seventh day after the injection of anti-Thy 1.1 antibody, the rats were killed and the kidneys were resected.

To determine the transfection efficiency, FITC-labeled E2F decoy ODN (200 $\mu$ g per animal) was transfected to normal Wistar rats as described above for the unlabeled ODNs. The incorporation of FITC-labeled ODN was evaluated by fluorescence microscopy.

Histologic examination. Kidney tissue from each animal was processed for evaluation by light and fluorescence microscopy and immunohistochemistry as described previously $(18,19)$. For light microscopy, the tissues were fixed in $10 \%$ buffered formalin and embedded in paraffin. Sections $(3 \mu \mathrm{m})$ were stained with periodic acid-Schiff. For fluorescence microscopy, the tissues were frozen in liquid nitrogen, and sections $4 \mu \mathrm{m}$ thick were used. To determine the glomerular cellularity, all sections were coded and read by an observer who was unaware of the study design. Glomerular cellularity was evaluated by counting the total number of nuclei in 30 representative glomerular cross sections that contained $>20$ discrete capillary segments per cross section.

Immunohistochemical staining for PCNA. Tissue was processed by an indirect immunoperoxidase technique as described previously with minor modifications (20). The primary antibody was monoclonal mouse anti-PCNA IgG (DAKO A/S, Glostrup, Denmark). The for- malin-fixed, paraffin-embedded sections were deparaffinized and washed briefly in distilled water. The sections then were boiled in $20 \% \mathrm{ZnSO}_{4}\left(7 \mathrm{H}_{2} \mathrm{O}\right)$ for $10 \mathrm{~min}$, washed briefly in distilled water, and blocked with $0.3 \%$ hydrogen peroxide. The samples then were incubated with primary antibody and subsequently processed using streptoavidin-biotin immunoperoxidase with $3,3^{\prime}$-diaminobenzidine as the chromogen. The sections also were counterstained with hematoxylin. 30 glomeruli in each specimen were examined and the mean number of PCNA positive cells per glomerulus was calculated. Negative controls were performed by substituting the primary antibody with an irrelevant murine monoclonal antibody.

Preparation of nuclear extract from $M C$. A nuclear extract was prepared from cultured human MCs $1 \mathrm{~h}$ after serum stimulation. The cells were scraped from 24-well plates (Costar Corp.) and washed

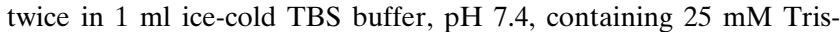
$\mathrm{HCl}, 130 \mathrm{mM} \mathrm{NaCl}$, and $5 \mathrm{mM} \mathrm{KCl}$. After centrifugation at 7,000 rpm for $30 \mathrm{~s}$ at $4^{\circ} \mathrm{C}$, the pellet was lysed in $800 \mu \mathrm{l}$ ice-cold homogenization buffer containing $10 \mathrm{mM}$ Hepes, $\mathrm{pH} 7.9 ; 10 \mathrm{mM} \mathrm{KCl} ; 0.1 \mathrm{mM}$ EDTA, pH 7.5; $0.1 \mathrm{mM}$ EGTA, pH 7.5; $1 \mathrm{mM}$ DTT; and $1 \mathrm{mM}$ PMSF and incubated for $15 \mathrm{~min}$ at $4^{\circ} \mathrm{C}$. Then $60 \mu \mathrm{l} 10 \%$ Nonidet P-40 was added, and the extract was centrifuged at $15,000 \mathrm{rpm}$ for $5 \mathrm{~min}$ at $4^{\circ} \mathrm{C}$. The nuclei were then extracted with $100 \mu l$ homogenization buffer containing 20 mM Hepes, pH 7.9; 400 mM NaCl; 1 mM EDTA, pH 7.5; $1 \mathrm{mM}$ EGTA, pH 7.5; $1 \mathrm{mM}$ DTT; and $1 \mathrm{mM}$ PMSF, and incubated for $15 \mathrm{~min}$ at $4^{\circ} \mathrm{C}$. After pelleting the extracted nuclei at $15,000 \mathrm{rpm}$ for $5 \mathrm{~min}$ at $4^{\circ} \mathrm{C}$, the supernatant fraction was stored in aliquots at $-80^{\circ} \mathrm{C}$. Protein concentrations were determined using the Bio-Rad protein determination system (Bio-Rad, Hercules, CA; reference 21) and BSA as a standard.

Electrophoretic mobility-shift assay. Nuclear extract was prepared from cultured MCs as described above. E2F decoy ODN was labeled with $\left[\gamma^{-32} \mathrm{P}\right] \mathrm{ATP}$ using T4 Poly-nucleotide Kinase (Promega Corp., Madison, WI). Binding reactions were performed with $10 \mu \mathrm{g}$ of nuclear extract in a binding buffer containing $20 \mathrm{mM}$ Hepes, $\mathrm{pH}$ 7.9, $10 \mathrm{mM} \mathrm{MgCl} 2,0.1 \mathrm{mM}$ EGTA, $0.1 \%$ Nonidet P-40, $10 \%$ glycerol, 0.5 $\mathrm{mM}$ DTT, and $3 \mu \mathrm{g}$ of sonicated salmon sperm DNA to which $10 \mathrm{ng}$ of ${ }^{32} \mathrm{P}$-labeled probe was added in a final volume of $30 \mu \mathrm{l}$. Reaction mixtures were incubated for $30 \mathrm{~min}$ at room temperature and loaded onto a $4 \%$ nondenaturing polyacrylamide gel and were electrophoresed. After electrophoresis, the gels were dried and DNA/nuclear protein complexes were detected by autoradiography. For competition experiments, 200-fold excess unlabeled ODN was incubated with the reaction mixture for $20 \mathrm{~min}$ before the addition of radiolabeled ODN.

Reverse transcription-PCR. Total cellular RNA was extracted from cultured human MCs $24 \mathrm{~h}$ after serum stimulation and from isolated glomeruli of Wistar rats (normal, untreated diseased, E2F decoy ODN- or mismatch control ODN-treated diseased rats; $n=4$ for each group) by the method of Chomczynski and Sacchi (22). The amount of total RNA was quantified spectrophotometrically and standarized according to the intensity of $18 \mathrm{~S}$ and $28 \mathrm{~S}$ rRNA expression. Aliquots of total RNA were reverse transcribed with random primers and M-MLV Reverse transcriptase (USB Biologicals, Cleveland, Ohio) to create cDNA, which was then amplified with Taq Polymerase (Perkin-Elmer Corp., Norwalk, CT) and specific primers for PCNA and glyceraldehyde-3-phosphate dehydrogenase (GAPDH) as described previously $(15,23)$. Each PCR cycle consisted of denaturation at $94^{\circ} \mathrm{C}$ for $1 \mathrm{~min}$, annealing at $55^{\circ} \mathrm{C}$ (PCNA) or $60^{\circ} \mathrm{C}$ (GAPDH) for $2 \mathrm{~min}$, and extension at $72^{\circ} \mathrm{C}$ for $3 \mathrm{~min}$. The samples were amplified for 35 cycles in a thermal cycler (TP cycler-100; Toyobo, Tokyo, Japan). Aliquots of the PCR products were electrophoresed on a $1.2 \%$ agarose gel, stained with ethidium bromide, and subjected to quantitative scanning densitometry. The sequences of the primer pairs used and the accuracy of this method in quantitating PCNA mRNA, have been described previously (15).

Statistical analysis. All values are expressed as mean \pm SD. ANOVA with a one tailed Student's $t$ test was used to identify significant differences in multiple comparisons. A level of $P<0.05$ was considered statistically significant. 


\section{Results}

\section{Cultured MCs}

Uptake and localization of FITC-labeled ODNs. We evaluated the efficiency of ODN uptake into MCs using FITC-labeled ODNs complexed with cationic liposomes. After incubation with the labeled ODNs for $20 \mathrm{~min},>60 \%$ of the MCs exhibited weak fluorescence in the cytoplasm and nucleus. After a 24-h incubation period, intense staining was observed in the cytoplasm and nuclei of $>90 \%$ of cells (Fig. 1). The nuclei consistently stained more intensely than the cytoplasm.

Effects of E2F-decoy ODN on MC proliferation. The effect of E2F decoy ODN was assessed by [ $\left.{ }^{3} \mathrm{H}\right]$ thymidine incorporation and direct cell count. Incubation of MCs with E2F decoy significantly decreased $\left[{ }^{3} \mathrm{H}\right]$ thymidine incorporation in a dosedependent manner compared with cells incubated with the mismatch control ODN (Fig. 2). Thus, 20\% FCS induced MC proliferation was suppressed by 78.5 and $83.4 \%$ after incubation with 2 and $10 \mu \mathrm{M}$ of E2F decoy ODN, respectively. The antiproliferative effect of the E2F decoy ODN was confirmed further by the results of direct cell count analysis. Again, the E2F decoy ODN inhibited MC proliferation significantly compared with the mismatch control ODN. The mean number of growth-stimulated MC was 14031.3 \pm 1855.1 in the absence of ODN per well, and $11300.0 \pm 572.8$ per well after the addition of mismatch control ODN. Addition of the E2F decoy ODN significantly reduced the cell number to $6250.4 \pm 696.0$ per well $(P<0.05)$. The amount of $\left[{ }^{3} \mathrm{H}\right]$ thymidine incorporation and cell number after E2F-decoy treatment were greater in growthstimulated $\mathrm{MC}$ than quiescent MC grown in $0.5 \% \mathrm{FCS}$, indicating that the ODN treatment was not toxic to the cells but only exerted a specific antiproliferative effect.

Electrophoretic mobility shift assay for E2F binding in vitro. To provide evidence that the E2F decoy ODN prevented the binding of E2F to its target sites, we performed an electrophoretic mobility-shift assay (EMSA) in the presence of the E2F decoy ODN or the mismatch control ODN. These analyses demonstrated that serum stimulation resulted in in-

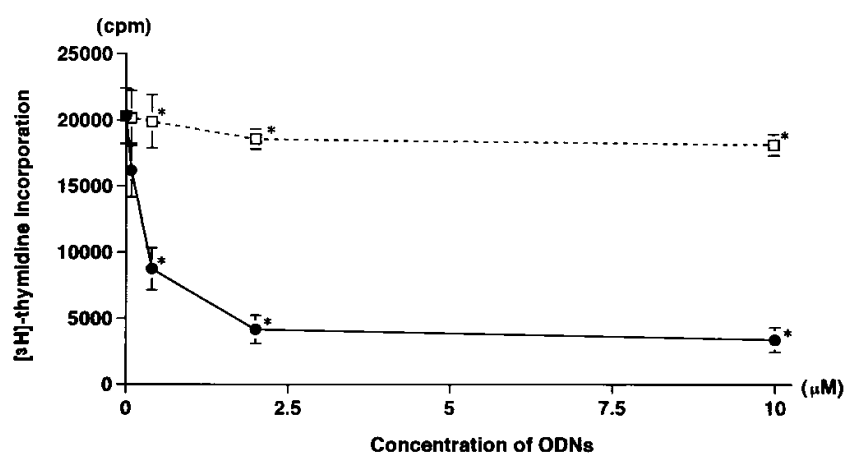

Figure 2. Effect of E2F decoy ODNs on MC proliferation as assessed by $\left[{ }^{3} \mathrm{H}\right]$-thymidine incorporation. The E2F-decoy ODN inhibited FCS $(20 \%)$ induced MC proliferation (incorporation of [ $\left.{ }^{3} \mathrm{H}\right]$-thymidine) in a concentration-dependent manner. The difference between the mean value of $\left[{ }^{3} \mathrm{H}\right]$-thymidine incorporation in the E2F decoytreated (black circles) and control mismatch ODN-treated (white squares) $\mathrm{MC}$ was significant $(P<0.05)$. Each point represents the mean \pm SD of four experiments. $* P<0.05$ by one tailed Student's $t$ test.

creased E2F binding activity in the MC nuclear extract. This increased E2F binding was abolished by treatment with E2F decoy ODN $(2 \mu \mathrm{M})$ whereas the addition of the mismatch control ODN did not inhibit E2F binding (Fig. 3). The data also show complete disappearance of the protein-DNA complex in the presence of the specific competitor, indicating that this DNA-protein interaction is highly specific.

Effects of E2F decoy ODN on PCNA $m R N A$ expression of $M C$. To confirm E2F decoy ODN specifically inhibited E2F binding, we investigated the effect of E2F decoy ODN on PCNA mRNA expression. Total RNA was extracted from MCs treated with $2 \mu \mathrm{M}$ of either E2F decoy ODN or mismatch control ODN, and the level of PCNA mRNA was assessed by

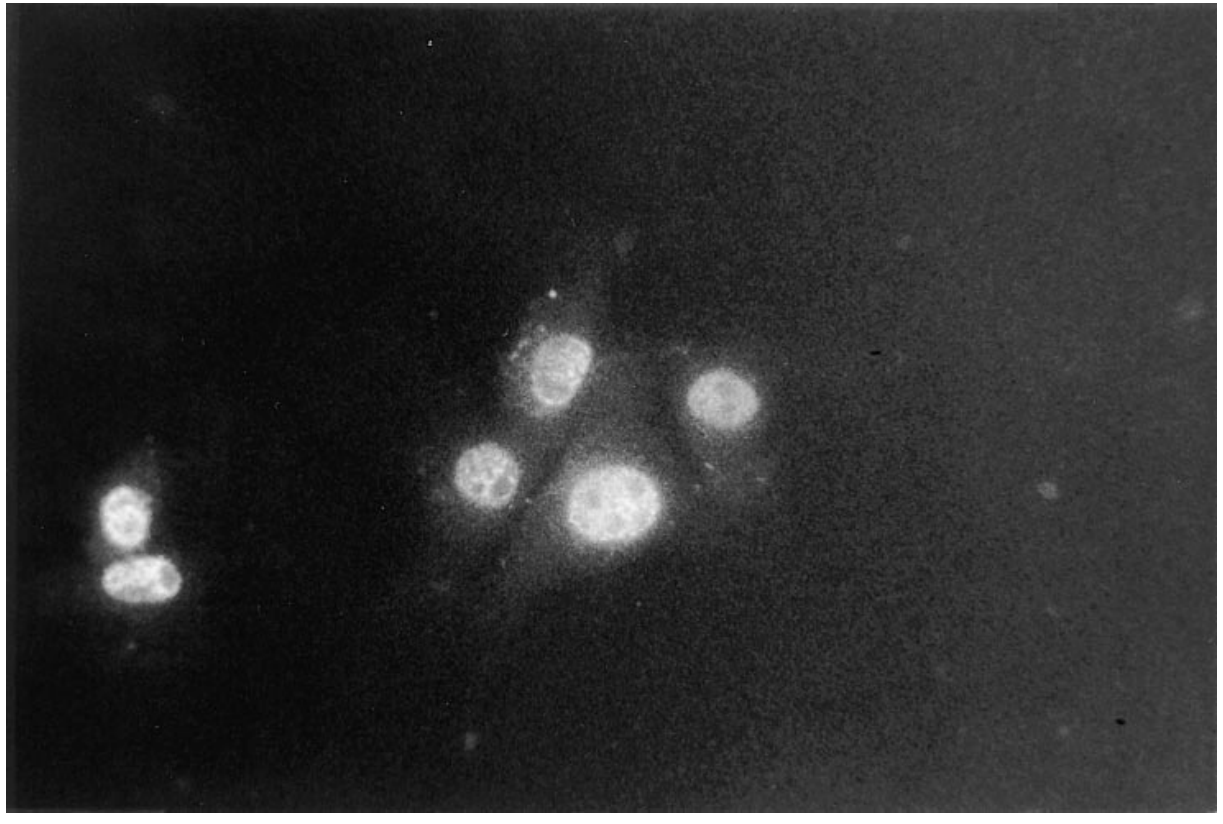

Figure 1. Representative fluorescence microscopy photograph of cultured human MCs transfected with FITClabeled double-stranded ODNs $(\times 400)$. MCs were observed $24 \mathrm{~h}$ after transfection of FITC-labeled ODNs. Staining was detectable in both the nuclei and the cytoplasm. 


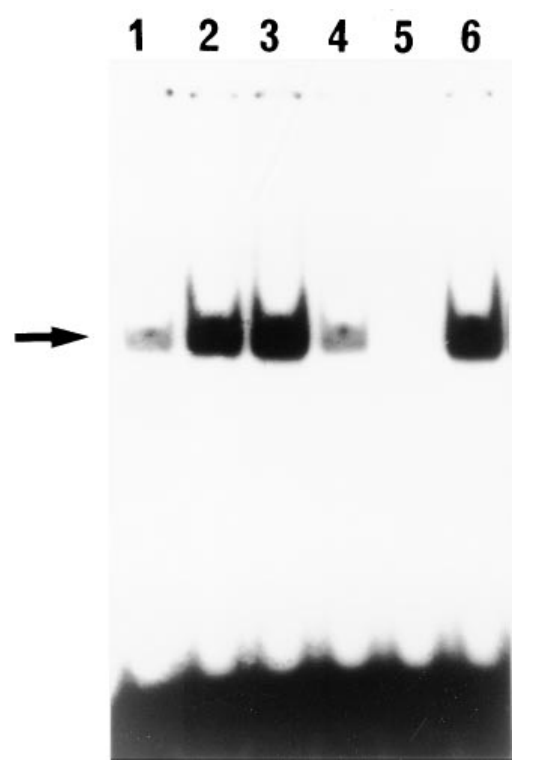

Figure 3. EMSA of the E2F binding site in vitro. Nuclear extract was obtained from the following groups: (a) serum-starved cultured MCs, lane 1; (b) serumstimulated MCs, lane 2. (c) serum-stimulated MCs transfected with mismatch ODN $(2 \mu \mathrm{M})$, lane 3 ; and $(d)$ serumstimulated MCs transfected with E2F decoy ODN $(2 \mu \mathrm{M})$, lane 4. Nuclear extract $(10 \mu \mathrm{g})$ was incubated with $\left[\gamma^{32} \mathrm{P}\right]$ ATP-labeled ODNs for $30 \mathrm{~min}$ at room temperature. The samples were electrophoresed on a $4 \%$ nondenaturing polyacrylamide gel, and visualized by autoradiography. For competition experiments, 200-fold excess unlabeled ODN (decoy ODN, lane 5; mismatch ODN, lane 6) was incubated with the reaction mixture for $20 \mathrm{~min}$ before the addition of radiolabeled ODN. The position of the E2F protein-DNA complex is indicated by an arrow.

reverse transcriptase (RT)-PCR. Cells treated with E2F decoy ODN contained decreased PCNA mRNA levels compared with cells treated with mismatch control ODN or untreated cells (Fig. 4). The GAPDH mRNA levels, in contrast, did not differ significantly between cells treated with E2F decoy ODN or mismatch control ODN.

\section{Rat anti-Thy 1.1 GN model}

Uptake and localization of FITC-labeled ODNs. We evaluated the efficiency of ODN uptake into glomerular cells using
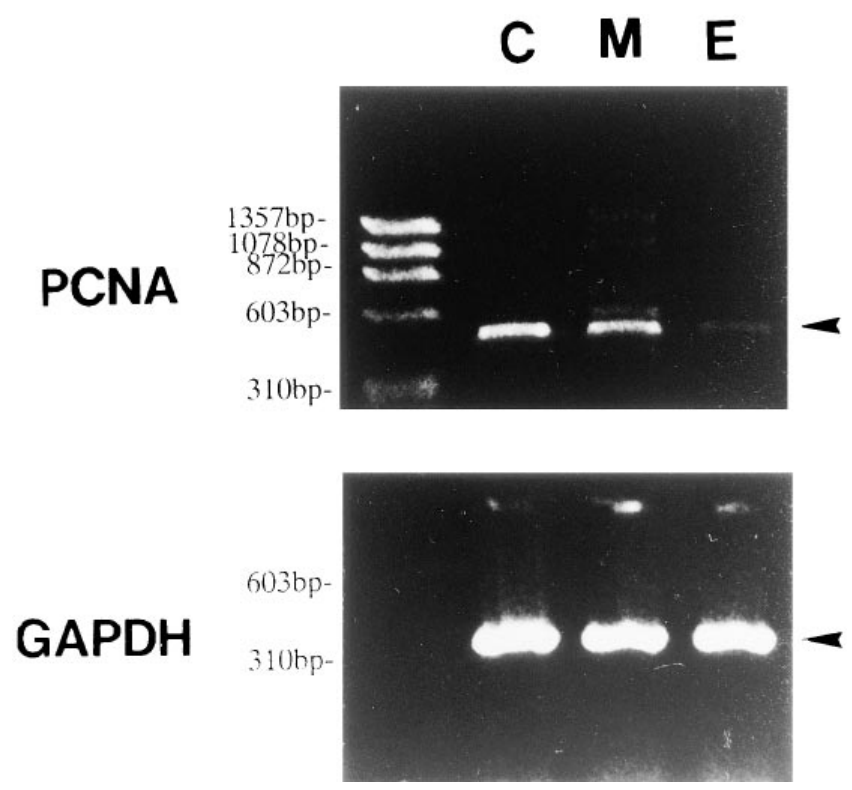

Figure 4. Effect of E2F decoy ODN transfection on MC expression of PCNA and GAPDH mRNA expression. mRNAs were detected by RT-PCR. $C$, serum-stimulated cultured MCs; $M$, serum-stimulated MCs transfected with the mismatch ODN; $E$, serum-stimulated MCs transfected with the E2F decoy ODN. Aliquots of the PCR products were electrophoresed on a $1.2 \%$ agarose gel and visualized by ethidium-bromide staining. The level of GAPDH mRNA in every sample was assessed as a control. The arrows indicate the position of the amplified cDNA.

FITC-labeled ODNs that were complexed with MLV-liposomes. $2 \mathrm{~h}$ after the intra-arterial injection of ODN the rats were killed. More than $60 \%$ of the glomeruli were positively stained with the fluorescence detectable mainly in the nuclei of the glomerular cells (Fig. 5). Most of the stained cells seemed to be MCs. Tubular and interstitial cells, in contrast, exhibited

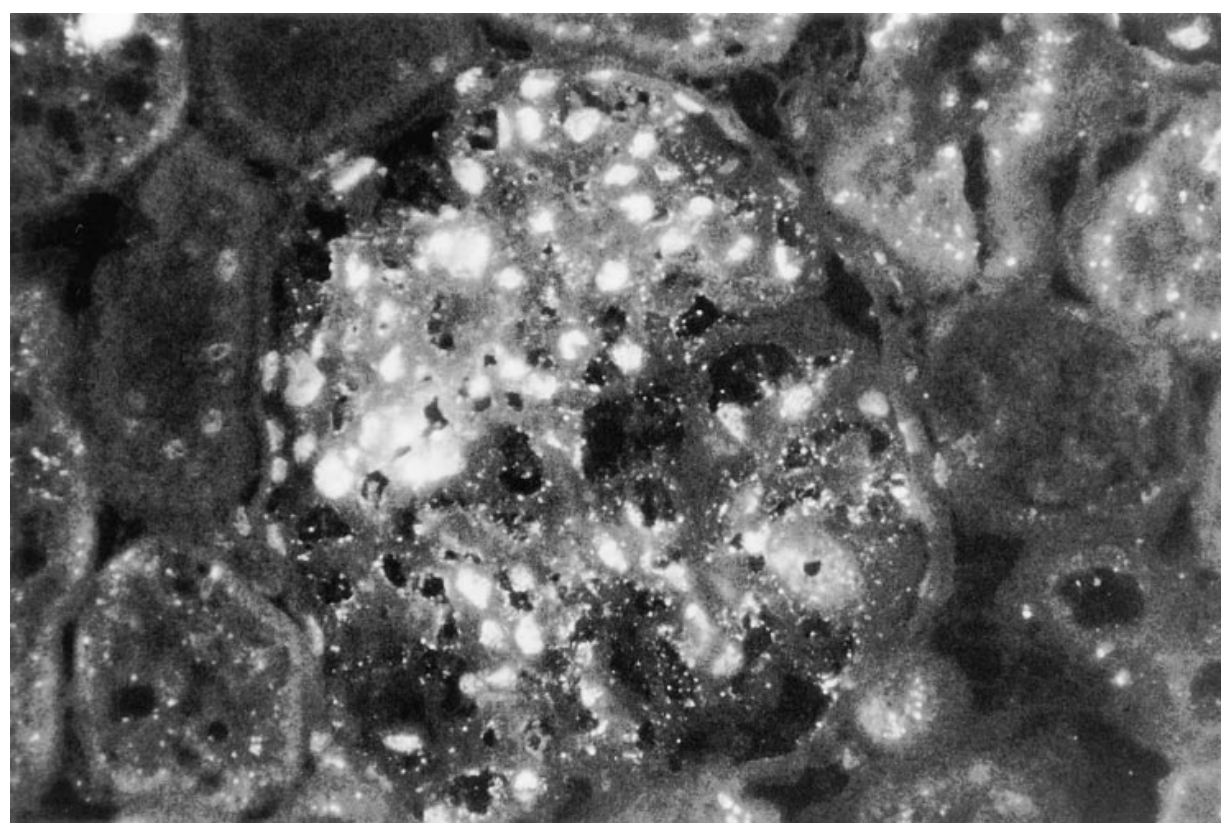

Figure 5. Representative fluorescence microscopy photograph of rat kidney tissue containing FITC-labeled ODNs $(\times 200)$. E2F decoy ODNs complexed with MLV-liposomes were introduced into the normal rat kidney via the left renal artery. $2 \mathrm{~h}$ after injection, the rats were killed. About $60 \%$ of the glomeruli exhibited fluorescence, mostly in the nuclei, in contrast to the surrounding tubular cells which exhibited low levels of fluorescence. 

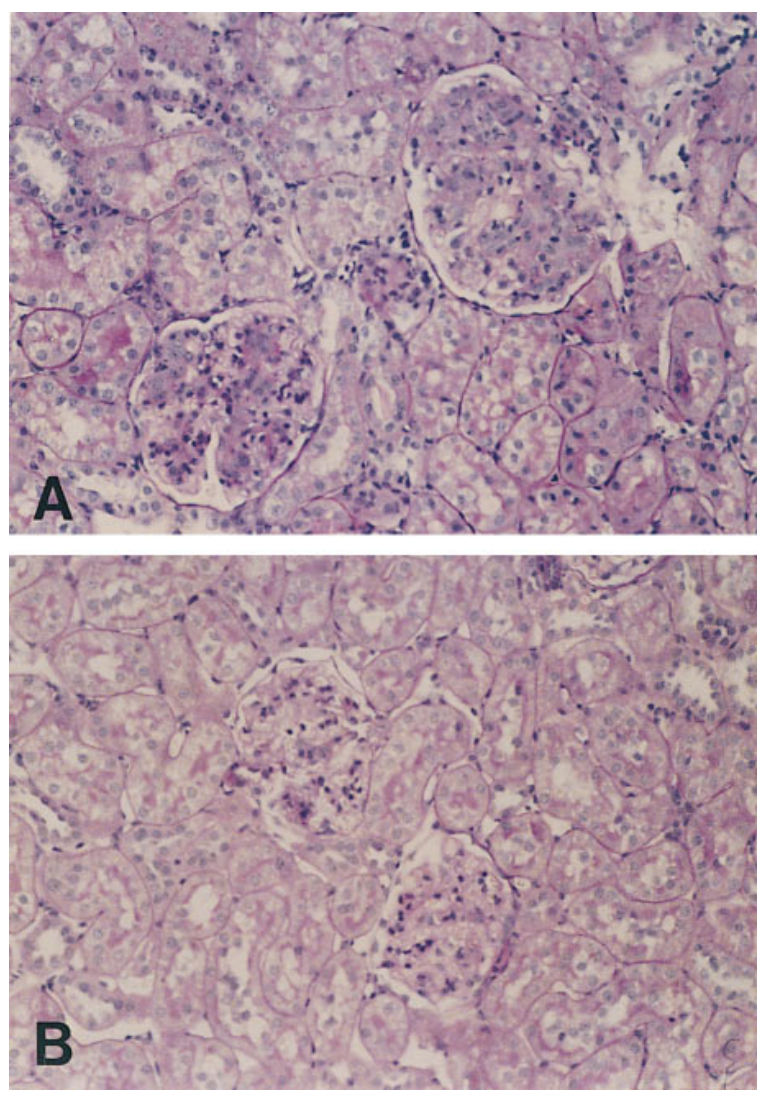

Figure 6. Effect of E2F-decoy treatment on glomerular cell proliferation and glomerular matrix expansion. Compared with rats with mesangial proliferative $\mathrm{GN}$ treated with mismatch control ODN $(A), \mathrm{E} 2 \mathrm{~F}$ decoy-ODN treated rats with GN $(B)$ had a significantly lower glomerular cellularity and exhibited less mesangial matrix expansion (periodic acid-Schiff stain). $\times 200$.

hardly any fluorescence. The MLV-liposome administration did not produce any apparent adverse effects on the animals. Fatal thrombosis or lethal damage were not observed throughout this experimental course.

Effect of E2F decoy ODN on glomerular cell proliferation. We evaluated the effect of E2F-decoy treatment on the proliferation of glomerular cells by microscopic analysis of kidney tissue from the normal rats, the diseased but untreated rats, and the rats treated with the decoy ODN or the mismatch control ODN. The total number of glomerular cells in untreated anti-Thy $1.1 \mathrm{GN}$-induced rats was significantly increased compared with undiseased control rats (Fig. 7). E2F decoy ODN treatment suppressed glomerular cell proliferation by $71.3 \%$ compared with untreated diseased rats (Figs. 6 and 7). Mismatch control-ODN treatment, in contrast exhibited little antiproliferative effects (Figs. 6 and 7). The specificity of the inhibitory effect of the E2F decoy ODN was supported further by the observation that vehicle-injected GN rats did not exhibit any significant changes in histological appearance compared with untreated GN rats. The total glomerular cell number of right kidneys (uninjected) after decoy treatment did not decrease compared with that of the left kidneys (rt, 99.9 \pm 6.7 cells/glom; lt, 59.2 \pm 5.8 cells/glom). Intra-arterial injection of the mismatch control ODN also did not affect the number of glomerular cells of the right kidneys (rt, 104.8 \pm 5.6 cells/glom; lt, $104.4 \pm 4.7$ cells/glom).

Effects of E2F decoy ODN on PCNA $m R N A$ and protein expression in vivo. To confirm E2F decoy ODN specifically inhibited E2F binding in vivo, we also analyzed the effect of E2F decoy treatment on PCNA protein and mRNA expression, using immunohistochemical staining and RT-PCR. E2F decoy treatment significantly inhibited PCNA protein expression in the glomeruli, whereas the mismatch control ODN had almost no effect (Figs. 8 and 9). Furthermore, glomerular PCNA mRNA levels were decreased in E2F decoy-treated rats compared with mismatch control-treated animals (Fig. 10). No significant difference in GAPDH mRNA levels was observed between the two groups of animals.

\section{Discussion}

The excessive proliferation of MCs is found in many types of chronic GN. Some studies suggest that MC proliferation and its activation are associated with the overexpression of extracellular matrix components, leading to the development of glomerulosclerosis $(1-4,24)$. MCs proliferate in response to a variety of growth factors or cytokines, including PDGF, basic fibroblast growth factor, IL-1, and IL-6 (25-30). These factors are released from such inflammatory cells as macrophages as well as by the platelets, and are also produced by MCs themselves. They exert their effects in an autocrine/paracrine manner $(25,26,31-33)$. Since the proliferation of MCs appears to

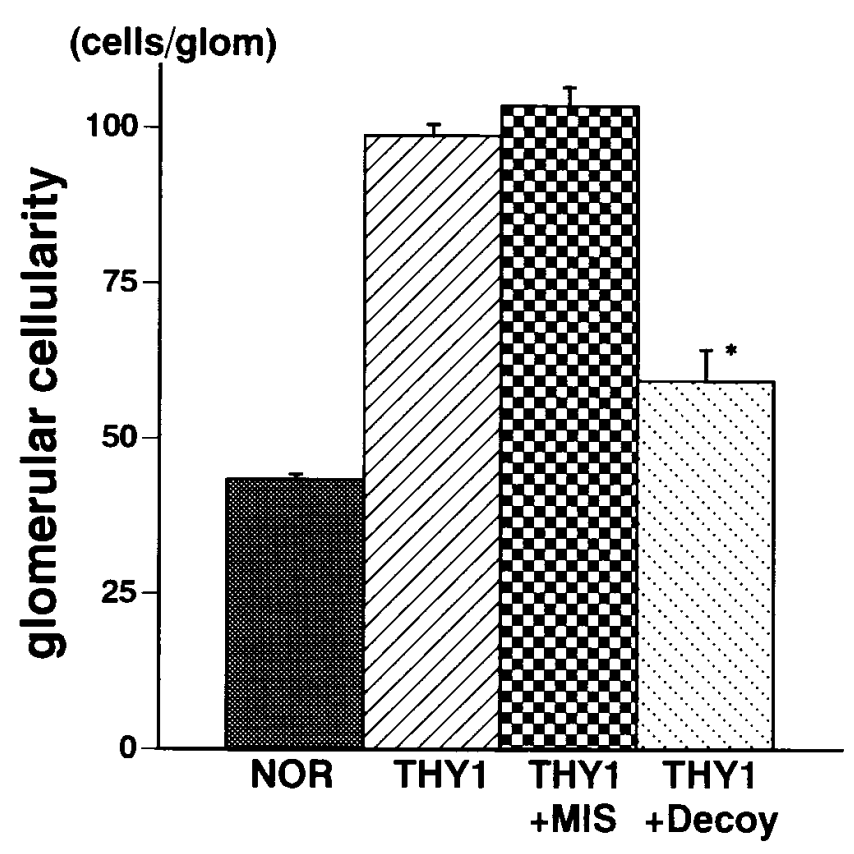

Figure 7. Effect of E2F decoy ODN on glomerular cell proliferation in rat anti-Thy $1.1 \mathrm{GN}$. NOR, normal rats $(n=4)$; THY1, anti-Thy 1.1 -induced GN rats $(n=4) ; T H Y 1+M I S$, anti-Thy 1.1-induced GN rats treated with mismatch control ODN $(n=4) ; T H Y 1+D e-$ coy, anti-Thy 1.1-induced GN rats treated with E2F decoy ODN $(n=4)$. The difference in mean glomerular cell number between E2F decoy-treated and mismatch control ODN-treated rats was significant $(P<0.01)$. Data are expressed as mean \pm SD. $* P<0.01$ versus THY1 and THY1 + MIS by one tailed Student's $t$ test. 


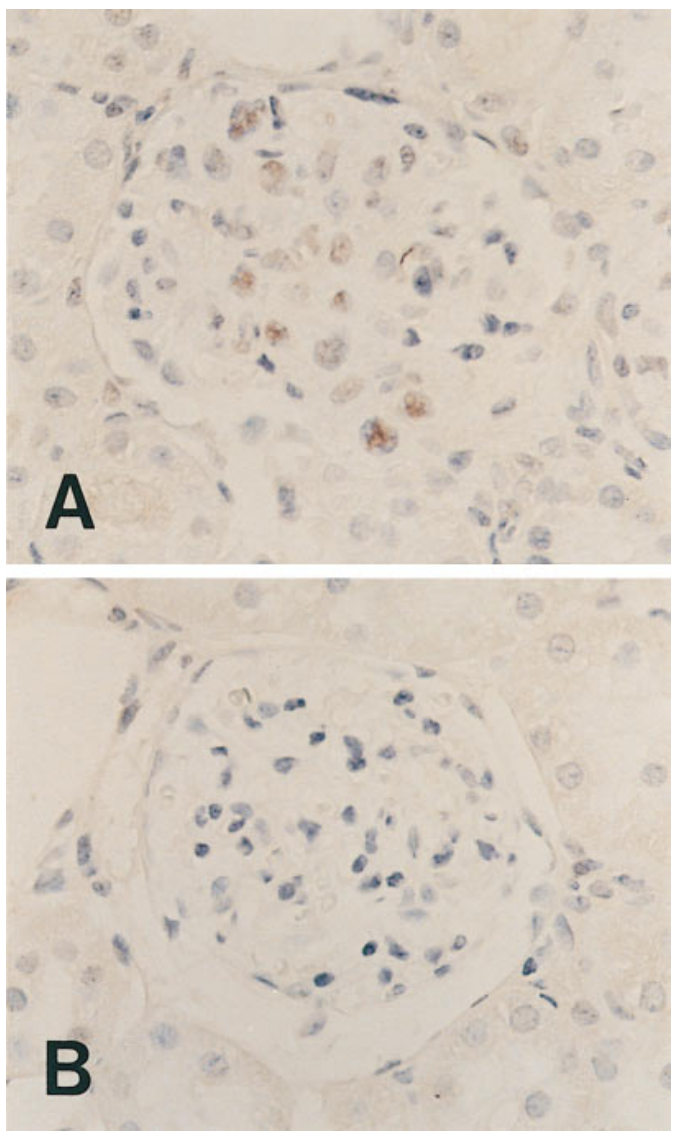

Figure 8. Effect of E2F decoy ODN transfection on in vivo glomerular expression of PCNA protein as determined by immunohistochemical staining for PCNA of representative glomeruli $(\times 200)$. $(A)$ PCNA expression is elevated in glomerular cells obtained from mismatch control ODN-treated rats with anti-Thy 1.1-induced GN. Most positive cells in the glomerular tuft seemed to be located in the mesangium. (B) PCNA expression is decreased significantly in the glomeruli of E2F decoy ODN-treated GN rats.

be an important pathological event that precedes glomerular sclerosis, several agents have been tested for their antiproliferative activity on the MCs. For example, since PDGF and TGF- $\beta$ are associated with MC proliferation and matrix expansion, some therapeutic approaches have been attempted to inhibit the activities of these growth factors. These studies found that antibodies to PDGF-BB or TGF- $\beta_{1}$ suppressed MC proliferation and/or matrix expansion in an experimental model of mesangial proliferative nephritis $(4,34)$. However, interventions targeting these mediators at the cell-surface level likely have only limited efficacy because of the multitude of mitogens and the redundancy of intracellular signal transduction pathways involved in MC proliferation $(35,36)$. Accordingly, interfering at a step in the final common pathway shared by diverse mitogenic signals appears to be a more promising approach to the inhibition of cellular proliferation.

$\mathrm{E} 2 \mathrm{~F}$ is a transcription factor that was originally identified through its role in the transcriptional activation of the adenovirus E2 promoter $(37,38)$. Subsequently, sequences homologous to the E2F-binding site were identified in the upstream regions of several genes encoding proteins with putative func- tions in the G1 and the S phases of the cell cycle. These included the genes for dihydrofolate reductase, DNA polymerase $\alpha$, thymidine kinase, thymidilate synthase, c-Myc, c-Myb, cyclin A, cdc2, retinoblastoma gene product and PCNA (8-10, $39,40)$. During the G0 and early G1 phase of the cell cycle, $\mathrm{E} 2 \mathrm{~F}$ exists in a complex with unphosphorylated $\mathrm{Rb}$ protein or the related protein $\mathrm{p} 107$. In this condition, E2F does not activate the transcription of its target genes. As the cells progress into the $\mathrm{S}$ phase, $\mathrm{Rb}$ protein and $\mathrm{p} 107$ are phosphorylated in cooperation with G1 cyclins (cyclins D and E), resulting in the release of E2F from the complex. The free E2F protein is transcriptionally active, and induces the coordinated transactivation of genes required for DNA synthesis, resulting in cell cycle progression (39). The critical role of E2F in cell growth control has been established by several previous studies showing that overexpression of various E2F proteins can induce otherwise quiescent cells to enter a cell cycle (41-43), and that overexpression of dominant negative E2F mutants inhibits cell cycle progression (44). Recently, a high affinity RNA ligand that specifically interacts with and blocks the DNA binding of the E2F proteins, was reported to inhibit cell proliferation (45). This cell cycle regulatory role and the finding that E2F was involved in the signaling pathways initiated by several mitogenic signals suggested that suppression of E2F activity

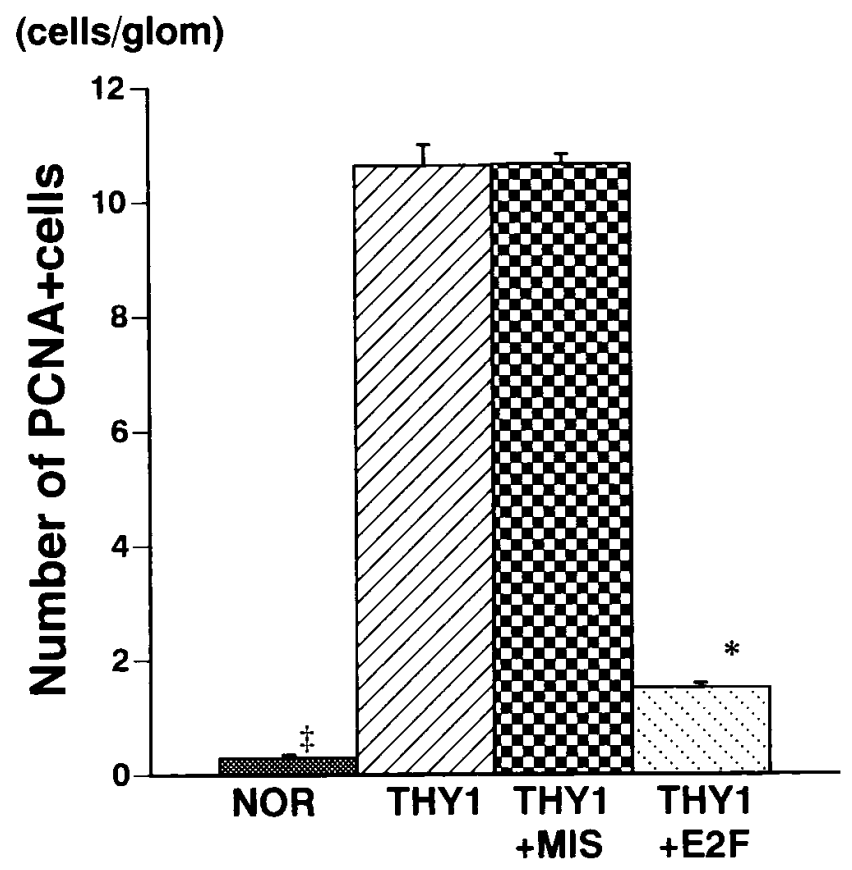

Figure 9. Effect of E2F decoy ODN on PCNA expression in rat antiThy 1.1-induced GN. The number of PCNA-positive cells per glomerulus was determined by immunohistochemical staining for PCNA. $N O R$, normal rats $(n=4)$; THY1, anti-Thy 1.1 -induced GN rats $(n=4) ; T H Y 1+M I S$, anti-Thy 1.1-induced GN rats treated with mismatch control ODN $(n=4) ;$ THY1 + Decoy: anti-Thy 1.1induced GN rats treated with E2F decoy ODN $(n=4)$. The difference between mean glomerular $\mathrm{PCNA}^{+}$cell number of E2F-decoytreated and mismatch ODN-treated was significant $(P<0.05)$. Data are expressed as mean \pm SD. $* P<0.05$ versus THY1, THY1 + MIS, and THY1 1 E2F; ${ }^{\ddagger} P<0.05$ versus THY1 and THY1 + MIS, by one tailed Student's $t$ test. 

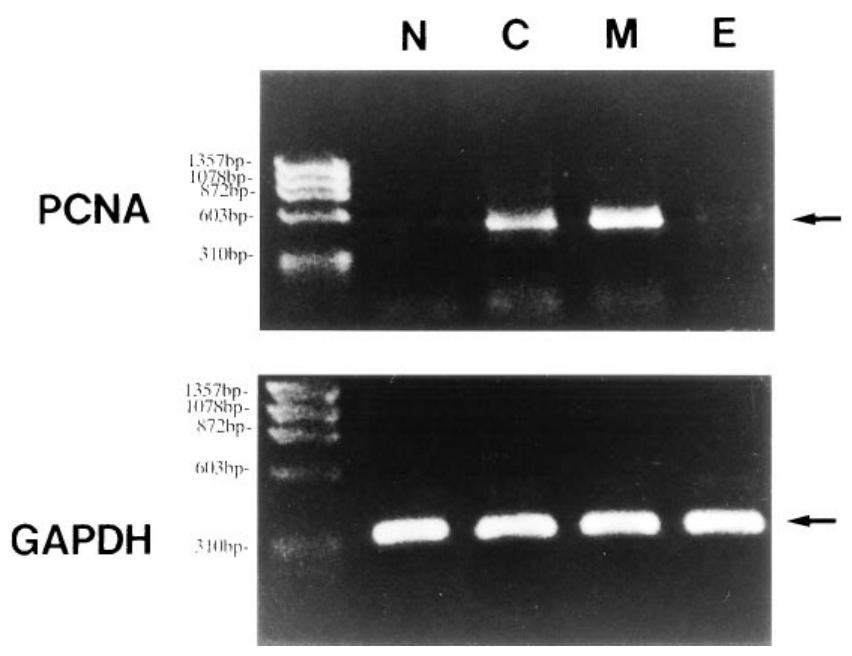

Figure 10. Effect of E2F decoy ODN transfection on in vivo glomerular expression of PCNA and GAPDH mRNA. mRNAs were detected by RT-PCR. $N$, normal rats; $C$, anti-Thy 1.1 -induced GN rats; $M$, anti-Thy 1.1-induced GN rats treated with mismatch ODN; $E$, anti-Thy 1.1-induced GN rats treated with E2F decoy ODN. Aliquots of the PCR products were electrophoresed on a $1.2 \%$ agarose gel, and visualized by ethidium-bromide staining. The level of GAPDH mRNA in every sample was assessed as a control. The arrowheads indicate the position of the amplified cDNA.

would effectively inhibit cell proliferation. In fact, a decoy strategy targeting E2F recently was reported to be quite effective in inhibiting smooth muscle cell proliferation (46).

Transcription factor-decoy technology has been developed to inhibit the expression of several genes using synthetic double-stranded ODNs containing the consensus binding sequence of a transcription factor. Several studies reported that ODNs with a high affinity for their target transcription factor, could be introduced into specific target cells and downregulated the transactivation of several genes in vitro $(47,48)$. A recent report also demonstrated the applicability of the decoy strategy in an in vivo system (46). However, this approach has not yet been employed to inhibit the cellular proliferation of renal cells and thus prevent the progression of proliferative $\mathrm{GN}$.

In this study we evaluated the capacity of an E2F-decoy ODN to inhibit MC proliferation, using a 25-bp ODN containing the consensus E2F binding sequence. In a previous study, Bielinska et al. (48) had employed double-stranded phosphorothioate ODN containing the NF- $\mathrm{BB}$ consensus sequence to inhibit transcription. We did not modify our ODNs, however, because modified ODNs such as phosphorothioate derivatives, are known to inhibit the protein synthesis of nontarget genes in a nonspecific, sequence-independent manner (49).

The success of decoy therapy depends on the efficiency with which the ODN is transfected into target cells. We have employed cationic liposomes to enhance the efficiency of ODN uptake into the MCs, based on results described previously (15). The validity of this approach was confirmed in vitro using FITC-labeled ODN. The antiproliferative effect of the E2F decoy ODN in vitro and its specificity were demonstrated using three different approaches: (a) E2F-decoy ODN significantly inhibited MC proliferation in a dose-dependent man- ner, whereas a mismatch control ODN did not; $(b)$ the E2F decoy, but not the mismatch control ODN, was a sequencespecific competitor of E2F binding sites as determined by EMSA; and (c) the E2F decoy, but not the control ODN, significantly suppressed PCNA mRNA expression. PCNA is a cofactor of DNA polymerase- $\delta$ and is essential for the process of DNA replication $(50,51)$, specifically for the progression from the G1 phase to the $S$ phase of the cell cycle. Because PCNA expression is low in quiescent cells, but increases after stimulation of the cells by growth factors such as PDGF, bFGF, and EGF (52), it frequently is used as a marker of cell proliferation. The upstream region of the PCNA gene contains the E2F binding site consensus sequence (10), making it a suitable control for confirming the ability of the E2F decoy ODN to inhibit transcriptional activation.

The antiproliferative effect of E2F-decoy treatment in cultured MCs prompted us to apply this approach in an in vivo system. Therefore, we examined the inhibitory effect of E2F decoy ODN on the progression of mesangial proliferative GN in a rat anti-Thy $1.1 \mathrm{GN}$ model. Injection of anti-Thy 1.1 antibody into rats results in rapid, complement-dependent loss of MCs with a concurrent disruption of the mesangial matrix (mesangiolysis; references 53,54 ). The early mesangiolysis on day 1 is followed by massive MC proliferation accompanied by the glomerular accumulation of various ECM components (55). To introduce the decoy ODN into the glomerular cells, we employed cationic MLV-liposomes. These liposomes previously have been shown to allow high levels of both transient and stable expression of minigenes because of their efficient encapsulation of the DNA, their high affinity for the cells resulting from their positively charged surface, and their low cytotoxicity (17). The results of preliminary experiments using FITC-labeled double-stranded ODN to transfect rat kidneys suggested that our transfection system might be efficient enough to introduce sufficient decoy ODN into the glomerular cells.

E2F-decoy treatment remarkably suppressed the proliferation of glomerular cells (i.e., $\mathrm{PCNA}^{+}$cells) and significantly reduced total glomerular cellularity. Renal glomeruli are composed of three types of resident cells: mesangial, endothelial, and epithelial cells (3). In addition, diseased glomeruli are infiltrated by inflammatory leukocytes. Although we could not identify clearly the proliferating cell, most of the proliferating cells in the anti-Thy 1 GN model have been shown to be MCs $(4,33)$. Therefore, we hypothesize that the E2F decoy suppressed glomerular MC proliferation. E2F-decoy treatment also markedly suppressed the expansion of the mesangial matrix. The reduced accumulation of ECM in the mesangium, may reflect, in part, the reduction in $\mathrm{MC}$ numbers. Taken together, these observations indicate that E2F-decoy treatment successfully inhibited the progression of mesangial proliferative GN. E2F-decoy treatment also reduced PCNA mRNA and protein expression in vivo, supporting the hypothesis that the decoy ODN served as a sequence-specific competitor of E2F-binding sites.

Previous studies had employed synthetic oligonucleotides as antisense compounds that selectively inhibit expression of target genes by interfering with the translation or processing of specific cellular mRNAs (52). Previously, we applied antisense technology successfully to inhibit MC proliferation or pathologic ECM accumulation within the glomeruli $(15,56)$. However, the usefulness of antisense agents is limited if the gene 
that encodes a target protein has not been cloned. Decoy therapy, in contrast, can be used to inhibit the function of DNAbinding proteins if the corresponding cis-acting regulatory elements have been characterized. Moreover, decoy ODNs can abolish the transcriptional activation of an entire group of genes that are regulated by the targeted transcription factor, whereas antisense ODNs only inhibit the expression of a single target gene. Finally, the decoy strategy may be more effective than the antisense approach in blocking constitutively expressed factors as well as the activities of multiple transcription factors that bind to the same consensus sequence $(46,48,57)$.

Several previous reports demonstrated that E2F-Rb complex repressed transcription upon binding to certain E2Fresponsive promoters $(58,59)$. The binding of $\mathrm{Rb}$ to $\mathrm{E} 2 \mathrm{~F}$ is controlled by phosphorylation of $\mathrm{Rb}$, and the phosphorylation state of $\mathrm{Rb}$ varies with the cell cycle, which is relatively underphosphorylated in the G1 phase, but is hyperphosphorylated as the cell approaches the $\mathrm{S}$ phase and remains phosphorylated until the late $\mathrm{M}$ phase. Therefore, E2F site was supposed to alternate between a positive and a negative element according to the phosphorylation state of $\mathrm{Rb}$. These findings prompted the hypothesis that, by repressing transcription, the $\mathrm{Rb} / \mathrm{E} 2 \mathrm{~F}$ complex may play an active role in suppressing progression through G1 until an appropriate signal triggers Rb phosphorylation and its release from E2F (60). Accordingly, we believe the role of $\mathrm{Rb} / \mathrm{E} 2 \mathrm{~F}$ complex may be to coordinate progression of the cell cycle. The level of active $\mathrm{Rb}$ in proliferating cells is supposed to be held in check by phosphorylation, resulting in insufficient $\mathrm{Rb}$ to bind all of the accumulating E2F (61). Thus, while $\mathrm{Rb} / \mathrm{E} 2 \mathrm{~F}$ complex accumulates, there is more free $\mathrm{E} 2 \mathrm{~F}$ than can be bound by $\mathrm{Rb}$ in a proliferative response. The antiproliferative capacity of decoy ODN may be mediated through binding to free E2F, which plays a major role in cell cycle progression.

Recently, Field et al. (62) reported that E2F-1 ${ }^{-1-}$ mice exhibited a number of defects in T cell development and speculated that E2F-1 functioned to positively regulate apoptosis and suppressed cell proliferation. A similar observation was reported by Yamasaki et al. (63), demonstrating that E2F-1 functions as a tumor suppressor. These observations were surprising, because overexpression of E2F-1 in tissue culture cells stimulated cell proliferation and was oncogenic (41-43). The formation of tumors in some tissues of $\mathrm{E} 2 \mathrm{~F}-1^{-1-}$ mice may indicate that transcriptional repression by $\mathrm{Rb} / \mathrm{E} 2 \mathrm{~F}-1$ complex plays an important role in the inhibition of abnormal cell proliferation. The E2F family consists of E2F-1, 2, 3, 4, and 5, and all E2Fs are structurally similar, having numerous conserved sequence blocks (64-69). Further, all E2Fs bind to the consensus E2F binding site (64-69). As E2F is a multigene family, the elimination of just one member (E2F-1) may induce compensatory overexpression of other family member genes resulting in tumorigenesis, and thus may well not eliminate the proliferative capacity of the cell (45). We believe E2F-decoy ODN inhibited the activity of all family members, because they were shown to bind to the consensus E2F binding site.

In summary, E2F-decoy ODNs inhibited the proliferation of $\mathrm{MC}$ both in vitro and in vivo, indicating that E2F is an essential transcription factor for MC proliferation. Our results suggest that a decoy strategy targeting E2F potentially would be effective in inhibiting the proliferation of MCs in various glomerular diseases. To fully realize the potential of decoy ODNs to serve as therapeutic agents, however, efficient drug delivery systems need to be developed that allow the selective, localized administration of these agents to the target organs to reduce the risk of adverse effects on other organs. Once this and other obstacles are overcome, however, decoy-ODN therapy may become a very potent and attractive strategy in the treatment of human chronic GN, especially because this approach can be used to suppress the transcriptional activation of an entire family of target genes.

\section{Acknowledgments}

A portion of this study was supported by research grant 09671167 from a grant-in-aid for Scientific Research from the Ministry of Education, Science and Culture of Japan, and by National Institutes of Health grant DK 28492 (Y.S. Kanwar)

\section{References}

1. Striker, L.J., E.P. Peten, S.J. Elliot, T. Doi, and G.E. Striker. 1991. Mesangial cell turnover: effect of heparin and peptide growth factors. Lab. Invest. 64:446-456.

2. Alpers, C.E., K.L. Hudkins, A.M. Gown, and R.J. Johnson. 1992. Enhanced expression of "muscle-specific" actin in glomerulonephritis. Kidney. Int. 41:1134-1142.

3. Klahr, S., G. Schreiner, and I. Ichikawa. 1988. The progression of renal disease. N. Engl. J. Med. 318:1657-1666.

4. Johnson, R.J., E. Raines, J. Floege, A. Yoshimura, P. Pritzl, C. Alpers, and R. Ross. 1992. Inhibition of mesangial cell proliferation and matrix expansion in glomerulonephritis in the rat by antibody to platelet derived growth factor. J. Exp. Med. 175:1413-1416.

5. Farnham, P.J., J.E. Slansky, and R. Kollmar. 1993. The role of E2F in the mammalian cell cycle. Biochim. Biophys. Acta. 1155:125-131.

6. Nevins, J.R. 1992. E2F: a link between the Rb tumor suppressor protein and viral oncoproteins. Science. 258:424-429.

7. Shan, B., C.Y. Chang, D. Jones, and W.H. Lee. 1994. The transcription factor E2F-1 mediates the autoregulation of RB gene expression. Mol. Cell. Biol. 14:299-309.

8. Thalmeier, K., H. Synovsik, R. Mertz, E.L. Winnacker, and M. Lipp. 1989. Nuclear factor E2F mediates basic transcription and transactivation by E1a of the human MYC promoter. Genes Dev. 3:527-536.

9. Dalton, S. 1992. Cell cycle regulation of the human cdc2 gene. EMBO (Eur. Mol. Biol. Organ.) J. 11:1797-1804.

10. Yamaguchi, M., Y. Hayashi, F. Hirose, S. Matsuoka, K. Shiroki, and A. Matsukage. 1992. Activation of the mouse proliferating cell nuclear antigen gene promoter by adenovirus type 12 E1A proteins. Jpn. J. Cancer Res. 83:609-617.

11. Striker, G.E., and L.J. Striker. 1985. Glomerular cell culture. Lab. Invest. 53:122-131.

12. Sugiyama, H., N. Kashihara, H. Makino, Y. Yamasaki, and Z. Ota. 1996. Reactive oxygen species induce apoptosis in cultured human mesangial cells. $J$. Am. Soc. Nephrol. 7:2357-2363.

13. Sterzel, R.B., D.H. Lovett, H.G. Foellmer, M.C. Perfetto, D. Blemesdefer, and M. Kashgarian. 1986. Mesangial cell hillocks: nodular foci of exaggerated growth of cells and matrix in prolonged cultures. Am. J. Pathol. 125:130-140.

14. Davies, M. 1994. The mesangial cell: a tissue culture view. Kidney. Int. 45:320-327.

15. Maeshima, Y., N. Kashihara, H. Sugiyama, H. Makino, and Z. Ota. 1996. Antisense oligonucleotides to proliferating cell nuclear antigen and Ki-67 inhibit human mesangial cell proliferation. J. Am. Soc. Nephrol. 7:2219-2229.

16. Morita, H., K. Maeda, M. Obayashi, T. Shinzato, A. Nakayama, Y. Fujita, I. Takai, H. Kobayakawa, I. Inoue, S. Sugiyama, et al. 1992. Induction of irreversible glomerulosclerosis in the rat by repeated injections of a monoclonal anti-Thy 1.1 antibody. Nephron. 60:92-99.

17. Yagi, K., H. Noda, H. Kurono, and N. Ohishi. 1993. Efficient gene transfer with less cytotoxicity by means of cationic liposomes. Biochem. Biophys. Res. Commun. 196:1042-1048.

18. Keane, W.F., and L. Raij. 1980. Impaired mesangial clearance of macromolecules in rats with chronic mesangial ferritin-antiferritin immune complex deposition. Lab. Invest. 43:500-508.

19. Sugiyama, H., N. Kashihara, H. Makino, Y. Yamasaki, and Z. Ota. 1996. Apoptosis in glomerular sclerosis. Kidney. Int. 49:103-111.

20. Johnson, R.J., R.L. Garcia, P. Pritzl, and C.E. Alpers. 1990. Platelets mediate glomerular cell proliferation in immune complex nephritis induced by anti-mesangial cell antibodies in the rat. Am. J. Pathol. 136:369-374.

21. Bradford, M.M. 1976. A rapid and sensitive method for the quantitation of microgram quantities of protein using the principle of protein-dye binding. Anal. Biochem. 72:248-254. 
22. Chomczynski, P., and N. Sacchi. 1987. Single-step method of RNA isolation by acid guanidium thio-cyanate-phenol-chloroform extraction. Anal. Biochem. 162:156-159.

23. Onbe, T., N. Kashihara, Y. Yamasaki, H. Makino, and Z. Ota. 1994. Expression of mRNAs of cytokines and growth factors in the experimental glomerulonephritis. Res. Commun. Mol. Pathol. Pharmacol. 86:131-138.

24. Floege, J., E. Eng, B.A. Young, and R.J. Johnson. 1993. Factors involved in the regulation of mesangial cell proliferation in vitro and in vivo. Kidney. Int. 43:S47-S54.

25. Abbot, F., J.J. Ryan, M. Ceska, K. Matsushima, C.E. Sarraf, and A.J. Rees. 1991. Interleukin-1 $\beta$ stimulates human mesangial cells to synthesize and release interleukins-6 and -8. Kidney. Int. 40:597-605.

26. Ruef, C., K. Budde, J. Lacy, W. Northemann, S. Baumann, B. Sterzel, and D.L. Coleman. 1990. Interleukin-6 is an autocrine growth factor for mesangial cells. Kidney. Int. 38:249-257.

27. Schultz, P.J., P.E. Dicorleto, B.J. Silver, and H.E. Abboud. 1988. Mesangial cells express PDGF mRNAs and proliferate in response to PDGF. Am. J. Physiol. 255:F674-F684.

28. Floege, J., E. Eng, B.A. Young, C.E. Alpers, T.B. Barrett, D.F. BowenPope, and R.J. Johnson. 1993. Infusion of platelet-derived growth factor or basic fibroblast growth factor induces selective glomerular mesangial cell proliferation and matrix accumulation in rats. J. Clin. Invest. 92:2952-2962.

29. Kashihara, N., Y. Watanabe, H. Makino, and Y.S. Kanwar. 1992. Interleukin-1 induced alterations in glomerular proteoglycans: biochemical and tissue autoradiographic aspects. J. Am. Soc. Nephrol. 3:203-213.

30. Kashihara, N., Y. Watanabe, H. Makino, E.I. Wallner, and Y.S. Kanwar. 1992. Selective decreased de novo synthesis of glomerular proteoglycans under the influence of reactive oxygen species. Proc. Natl. Acad. Sci. USA. 89: 6309-6313.

31. Floege, J., E. Eng, V. Lindner, B.A. Young, M.A. Reidy, and R.J. Johnson. 1992. Rat glomerular mesangial cells synthesize basic FGF: release, upregulated synthesis and mitogenicity in mesangial proliferative glomerulonephritis. J. Clin. Invest. 90:2362-2369.

32. Mackay, K., L.J. Striker, J.W. Stauffer, T. Doi, L.Y. Agodoa, and G.E. Striker. 1989. Transforming growth factor- $\beta$ : murine glomerular receptors and responses to isolated glomerular cells. J. Clin. Invest. 83:1160-1167.

33. Iida, H., R. Seifert, C.E. Alpers, R.G.K. Gronwald, P.E. Phillips, P. Pritzl, K. Gordon, A.M. Gown, R. Ross, D.F. Bowen-Pope, and R.J. Johnson. 1991. Platelet-derived growth factor (PDGF) and PDGF receptor are induced in mesangial proliferative nephritis in the rat. Proc. Natl. Acad. Sci. USA. 88: $6560-6564$

34. Border, W.A., S. Okuda, L.R. Languino, M.B. Sporn, and E. Ruoslahti. 1990. Suppression of experimental glomerulonephritis by antiserum against transforming growth factor $\beta 1$. Nature. 346:371-374.

35. Shin, S.H., Y. Fujiwara, T. Takama, S. Ochi, A. Wada, M. Fukunaga, Y. Orita, T. Kamada, and K. Tagawa. 1989. Analysis of inositol tris-and tetrakisphosphate in mesangial cells by HPLC. Kidney. Int. 35:1320-1323.

36. Force, T., J.M. Kyriakis, J. Avruch, and J. Bonventre. 1991. Endothelin, vasopressin, and angiotensin II enhance tyrosine phosphorylation by protein kinase C-dependent and independent pathways in glomerular mesangial cells. $J$. Biol. Chem. 266:6650-6656.

37. Kovesdi, I., R. Reichel, and J.R. Nevins. 1986. Identification of a cellular transcription factor involved in E1A trans-activation. Cell. 45:219-228.

38. Yee, A.S., P. Raycaudhuri, L. Jakoi, and J.R. Nevins. 1989. The adenovirus-inducible factor E2F stimulates transcription after specific DNA binding. Mol. Cell. Biol. 9:578-585.

39. Chittenden, T., D.M. Livingston, and W.G. Kaelin. 1992. The T/E1Abinding domain of the retinoblastoma product can interact selectively with a sequence-specific DNA-binding protein. Cell. 65:1073-1082.

40. Watson, R.J., P.J. Dyson, and J. McMahon. 1987. Multiple c-myb transcript cap sites are variously utilized in cells of mouse haemopoietic origin. EMBO (Eur. Mol. Biol. Organ.) J. 6:1643-1651.

41. Asano, M., J.R. Nevins, and R.P. Wharton. 1996. Ectopic E2F expression induces $\mathrm{S}$ phase and apoptosis in Drosophila imaginal discs. Genes Dev. 10: $1422-1432$

42. DeGregori, J., G. Leone, K. Ohtani, A. Miron, and J.R. Nevins. 1995. E2F1 accumulation bypasses a G1 arrest resulting from the inhibition of G1 cyclin-dependent kinase activity. Genes Dev. 9:2873-2887.

43. Johnson, D.G., J.K. Schwarz, W.D. Cress, and J.R. Nevins. 1993. Expression of transcription factor E2F1 induces quiescent cells to enter S phase. Nature. 365:349-352.

44. Dobrowolski, S.F., D.W. Stacey, M.L. Harter, J.T. Steine, and S.W. Hiebert. 1994. An E2F dominant negative mutant blocks E1A induced cell cycle progression. Oncogene. 9:2605-2612.

45. Ishizaki, J., J.R. Nevins, and B.A. Sullenger. 1996. Inhibition of cell proliferation by an RNA ligand that selectively blocks E2F function. Nat. Med. 2:
1386-1389.

46. Morishita, R., G.H. Gibbons, M. Horiuchi, K.E. Ellison, M. Nakajima, L. Zhang, Y. Kaneda, and V.J. Dzau. 1995. A gene therapy strategy using a transcriptional factor decoy of the E2F binding site inhibits smooth muscle cell proliferation in vivo. Proc. Natl. Acad. Sci. USA. 92:5855-5859.

47. Sullenger, B.A., H.F. Gallardo, G.E. Ungers, and E. Gilboa. 1990. Overexpression of TAR sequences renders cells resistant to human immunodeficiency virus replication. Cell. 63:601-608.

48. Bielinska, A., R.A. Shivdasani, L. Zhang, and G.J. Nabel. 1990. Regulation of gene expression with double-stranded phosphorothioate oligonucleotides. Science. 250:997-1000.

49. Woolf, T.M., D.A. Melton, and C.G.B. Jennings. 1992. Specificity of antisense oligo-nucleotides in vivo. Proc. Natl. Acad. Sci. USA. 89:7305-7309.

50. Prelich, G., C.K. Tan, M. Kostura, M.B. Mathews, A.G. So, K.M. Downey, and B. Stillman. 1992. Functional identity of proliferating cell nuclear antigen and a DNA polymerase $\delta$ auxiliary protein. Nature. 326:517-520.

51. Bravo, R., R. Frank, P.A. Blundell, and B.H. Macdonald. 1987. Cyclin/ PCNA is the auxiliary protein of DNA polymerase d. Nature. 326:515-517.

52. Jaskulski, D., C. Gatti, S. Travali, B. Calabretta, and R. Baserga. 1988. Regulation of the proliferation cell nuclear antigen cyclin and thymidine kinase mRNA levels by growth factors. J. Biol. Chem. 263:10175-10179.

53. Yamamoto, T., and C.B. Wilson. 1987. Quantitative and qualitative studies of antibody-induced mesangial damage in the rat. Kidney. Int. 32:514-525.

54. Baggchus, W.M., P.J. Hoedemaeker, J. Rozing, and W.W. Bakker. 1986. Glomerulo-nephritis induced by monoclonal anti-Thy 1.1 antibodies. Lab. Invest. 55:680-687.

55. Floege, J., R.J. Johnson, K. Gordon, H. Iida, P. Pritzl, A. Yoshimura, C. Campbell, C E. Alpers, and W.G. Couser. 1991. Increased synthesis of extracellular matrix in mesangial proliferative nephritis. Kidney. Int. 40:477-488.

56. Kashihara, N., Y. Maeshima, H. Sugiyama, T. Sekikawa, K. Okamoto, Y. Morita, K. Kanao, Y. Yamasaki, H. Makino, Z. Ota, et al. 1995. Inhibition of mesangial cell proliferation and matrix expansion by antisense oligonucleotides. In Recent Advances in Molecular Nephrology. M. Arakawa and Y. Nakagawa, editors. KOHKO-DO/Niigata, Japan. 1-11.

57. Kashihara, N., Y. Maeshima, and H. Makino. 1997. Therapeutic intervention in glomerulonephritis by oligonucleotides. Exp. Nephrol. 5:126-131.

58. Weintraub, S.J., C.A. Prater, and D.C. Dean. 1992. Retinoblastoma protein switches the E2F site from positive to negative element. Nature. 358:259-261.

59. Qin, X., D.M. Livingston, M. Ewen, W.R. Sellers, Z. Arany, and J.W.G. Kaelin. 1995. The transcription factor E2F-1 is a down stream target of RB action. Mol. Cell. Biol. 15:742-755.

60. Sellers, W., J. Rodgers, and W. Kaelin. 1995. A potent transrepression domain in the retinoblastoma protein induces a cell cycle arrest when bound to E2F sites. Proc. Natl. Acad. Sci. USA. 92:11544-11548.

61. Ikeda, M., L. Jakoi, and J.R. Nevins. 1996. A unique role for the Rb protein in controlling E2F accumulation during cell growth and differentiation. Proc. Natl. Acad. Sci. USA. 93:3215-3220.

62. Field, S.J., F.Y. Tsai, F. Kuo, A.M. Zubiaga, J.W.G. Kaelin, D.M. Livingston, S.H. Orkin, and M.E. Greenberg. 1996. E2F-1 functions in mice to promote apoptosis and suppress proliferation. Cell. 85:549-561.

63. Yamasaki, L., T. Jacks, R. Bronson, E. Goilot, E. Harlow, and N.J. Dyson. 1996. Tumor induction and tissue atrophy in mice lacking E2F-1. Cell. 85:537-548.

64. Ivey-Hoyle, M., R. Conroy, H.E. Huber, P.J. Goodhart, A. Oliff, and D.C. Heimbrook. 1993. Cloning and characterization of E2F-2, a novel protein with the biochemical properties of transcription factor E2F. Mol. Cell. Biol. 13 $7802-7812$.

65. Lees, J.A., M. Saito, M. Vidal, M. Valentine, T. Look, E. Harlow, N. Dyson, and K. Helin. 1993. The retinoblastoma protein binds to a family of E2F transcription factors. Mol. Cell. Biol. 13:7813-7825.

66. Shan, B., X. Zhu, P.L. Chen, T. Durfee, Y. Yang, D. Sharp, and W.H. Lee. 1992. Molecular cloning of cellular genes encoding retinoblastoma-associated proteins: identification of a gene with properties of the transcription factor E2F. Mol. Cell. Biol. 12:5620-5631.

67. Helin, K., J.A. Lees, M. Vidal, N. Dyson, E. Harlow, and A. Fattaey. 1992. A cDNA encoding a pRB-binding protein with properties of the transcription factor E2F. Cell. 70:337-350.

68. Kaelin, W.G.J., W. Krek, W.R. Sellers, J.A. DeCaprio, F. Ajchenbaum, C.S. Fuchs, T. Chittenden, Y. Li, P.J. Farnham, M.A. Blanar, et al. 1992. Expression cloning of a cDNA encoding a retinoblastoma-binding protein with E2F-like properties. Cell. 70:351-364.

69. Sardet, Y., M. Vidal, D. Cobrinik, Y. Geng, C. Onufryk, A. Chen, and R.A. Weinberg. 1995. E2F-4 and E2F-5, two members of the E2F family, are expressed in the early phases of the cell cycle. Proc. Natl. Acad Sci. USA. 92. 2403-2407. 